\title{
Surface Capacity of Gears of Circular-Arc Tooth-Profile
}

\author{
Ahmert as. W. El-Bahlowt \\ Associale Professor Prodiction Eng. Dept. \\ Foculy of Engineantr - Mamsotra amiversity \\ Monsnitra. EGYPT
}

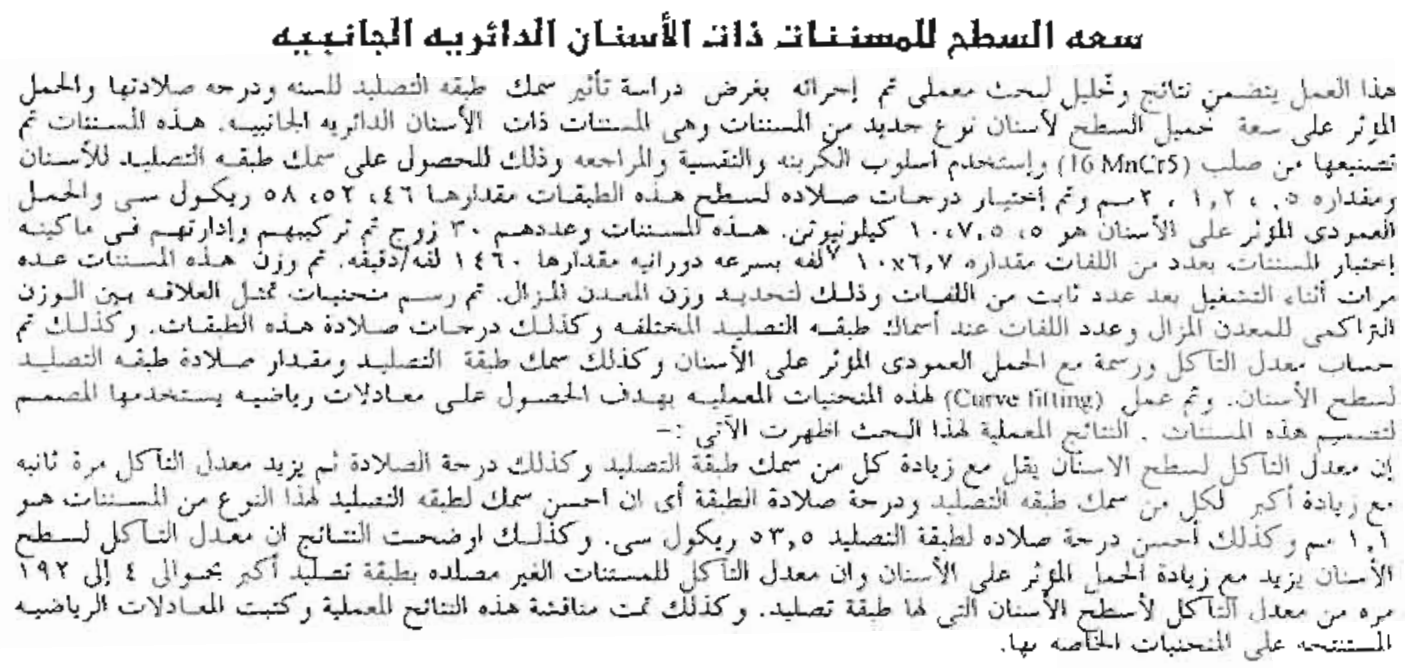

\section{ABSTRACT}

The peper embodies results and analysis of an experimental investigation carried oul io study the effect of case depth. case hardness and looth load on the surface capacity of a relatively new type of gearing having leeth of circular arc proliles. These gears were manulactured irom 16 MrCr5. Curburizing, quenching and tempering techniques were used wilh 0.5 .1 .2 and 2 $\mathrm{mm}$ case depth and 46, 52 and 58 HRC case hardness. also applied looth loads 5 . 75 and $10 \mathrm{KN}$ were used. These thirty pairs of gears were run to $6.7 \times 10^{7}$ revolutions at speod $1460 \mathrm{pm}$ in a power clrculating gear lest rilg using lorced lubricallon technique. Tesl gears were weiged at interval of times. the accumulated weight of remowed metal were drawn with the number of revolutions. Wear rate was calculated and drawn with the aoplied loolh load case deoth and case hardness. A curve liting was made for these experimental results using Grapher soltware. Results show that an optimum case depth of the case hardened gears of circular arc tooth profle equal $101.1 \mathrm{~mm}$ and also optimum case hardness of the case equal to 53.5 HRC. Wear rate frcreases with increasing the applied tooth load. Wear rate for unhardened gears increases by 4 to 192 imes than that of the case hardened gears. An empirica! tormulae for the accumulated weigh of removed metal with number of revolution, wear rate with looth ioad, case depth and case hardness were derived, also presented on the curves and discussed.

\section{INTRODUCTION}

Gears are usually desfgned for load carrying capacity for bending strength (tooth breakage) andlor load carrying capacity for surface strength (toolh wearl. Tooth surface failure resulss in wear which beside changing the accuracy of the designed gear running may results in decrease of tooth thickness which may cause bending strength lailure. Many investigators(1.5] have studfed the wear characteristle of unhardened gears of circular-arc tooth-profile To increase surface durability, beside main design considerations regarding the choice of material and design dimensions, several methods are adopled to decrease wear as: 
a- Mechanical surfaca hardening (cold-Working method) such as shol-peening

b- Surlace hardening such as lame hardening. hardening in electrolytic hath and induction bardening.

c. Chemical-thermal treatments (case hardening) such as carburizing. nilriding. cyaniding. carbunitriting, plasma nilriding, solt bath nitrocarburizing. boronizing, chromizing, luffriding and sur-sulfing.

Many investlgators[6-8] studied the surface durabilily lor involute gears ustng heal trealmenl lechniques.

The aim of this work is to study the effect of case depth, case hardness and tooth load on the surface capacity (wear rate) for case hardened gears of circular-arc tooth-prolite, also select the opthmum conditions of the case depth and its hardness. The effect of module. helix angle. speed of rotatlon, and olf viscosity on the wear rate and surface capacity for case hardened gears of circular-arc tooth-proflie are done [under publication].

\section{THE TEST GEARS}

Test gears are of convex all addendum pinion profile and concave wheel tooth profile[9-13]. Contact between teeth is point moving in a straight line along the helical tooth. There is no conjugacy between the teeth profiles except along the helical face. Thus such gears transmit power and motion along the path of tooth contact, with the point of contact of the two profiles changing under load to an elllpse. In these circumstances the problem of tribology applied to this type of gearing is of a complex nature. Fig.(1) shows one pair of lest gears with the convex and concave teeth in mesh. Table (1) shows the specifications and the main dimensions of the test gears. while table (2) shows the chemical composition and mechanical properties.

\begin{tabular}{|c|c|c|}
\hline & Pinion & Wheel \\
\hline Number of pairs & \multicolumn{2}{|c|}{$\begin{array}{l}30 \\
6 .(4233)\end{array}$} \\
\hline Normal diametral pitch or (module. $\mathrm{mm}$ ) & \multicolumn{2}{|c|}{$\begin{array}{l}6(4.233) \\
91.5\end{array}$} \\
\hline Normal pressure angle, deg & \multicolumn{2}{|c|}{25} \\
\hline Helix angle, deg & \multicolumn{2}{|c|}{223} \\
\hline Face width, mm & \multicolumn{2}{|c|}{42} \\
\hline Number of teeth & \multicolumn{2}{|c|}{20} \\
\hline Axial pitch, $\mathrm{mm}$ & \multicolumn{2}{|c|}{35} \\
\hline Fadif of curvature in normal plane, $\mathrm{mm}$ & 8,4667 & 9.525 \\
\hline Riadli of curvature along helix angle. $\mathrm{mm}$ & 314.884 & 341.255 \\
\hline Blank diameter, mm & 103.735 & 90.170 \\
\hline Overiap ratio & \multicolumn{2}{|c|}{1.2} \\
\hline Surface roughness, $\mu$ & \multirow{2}{*}{\multicolumn{2}{|c|}{$\begin{array}{c}1.6 \\
0.423\end{array}$}} \\
\hline Backlash, mm & & \\
\hline Bore diameter, mm & \multicolumn{2}{|c|}{$30+0.009$} \\
\hline
\end{tabular}

Table (1) Dimensions and specilications of tho test gears

\begin{tabular}{|c|c|c|c|c|c|c|}
\hline Element & $\mathrm{C}$ & $\mathrm{St}$ & $\mathrm{Mn}$ & $\mathrm{P}$ & $\mathrm{S}$ & $\mathrm{Ct}$ \\
\hline Weight & 0.14 & 0.15 & 1.00 & 0.035 & 0.035 & 0.8 \\
parcent & 0.19 & 10 & 10 & maximum & maximum & 10 \\
1.4 & 1.30 & & & 10 \\
\hline
\end{tabular}

Tablg (2) Chamical composilion of case hardening stgei usod for manuacturing test gears

\begin{tabular}{|c|c|c|c|c|c|c|}
\hline \multicolumn{2}{|c|}{ Sleel grade } & \multicolumn{5}{|c|}{100 to $160 \mathrm{~mm}$ diameler } \\
\hline $\begin{array}{c}\text { Code } \\
\text { number }\end{array}$ & $\begin{array}{l}\text { Material } \\
\text { numbar }\end{array}$ & $\begin{array}{l}\text { Yigld point } \\
\mathrm{Kg} / \mathrm{mm}^{2} \\
\text { min }\end{array}$ & $\begin{array}{l}\text { Tensile } \\
\text { strength } \\
\mathrm{Kg} / \mathrm{mm}^{2}\end{array}$ & $\begin{array}{c}\text { Elongation } \\
L_{0}=5 d_{0} \\
x \mathrm{~min}\end{array}$ & $\begin{array}{l}\text { Reduclion } \\
\text { of area } \\
\text { x min }\end{array}$ & $\begin{array}{c}\text { Notched bat impacl } \\
\text { strongth } \mathrm{Kg} . \mathrm{m} / \mathrm{cm}^{2} \\
\mathrm{~min}\end{array}$ \\
\hline $16 \mathrm{WhCH}$ & 1,7131 & 60 & 90 & 11 & 50 & 34 \\
\hline
\end{tabular}

Table (3) Mechancal propertes of case hardening stẹt used ror manulacturing last gears 


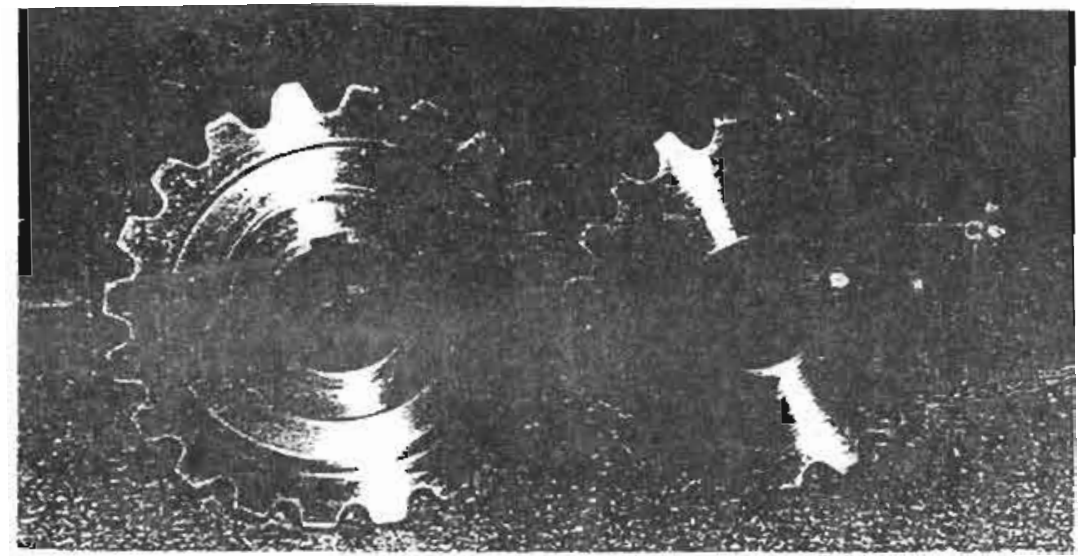

Figlilpair of test gears $-22.3^{\circ}$ helix angle.

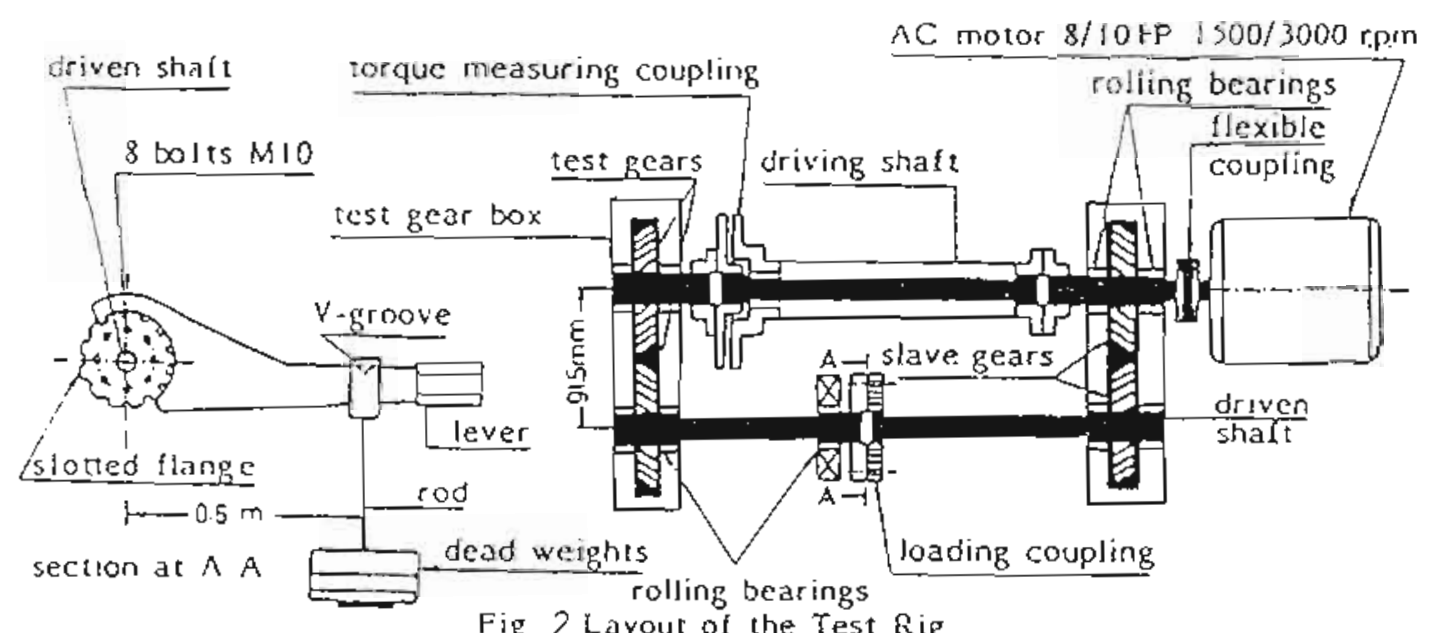

Fig 2 Layout of the Test Rig

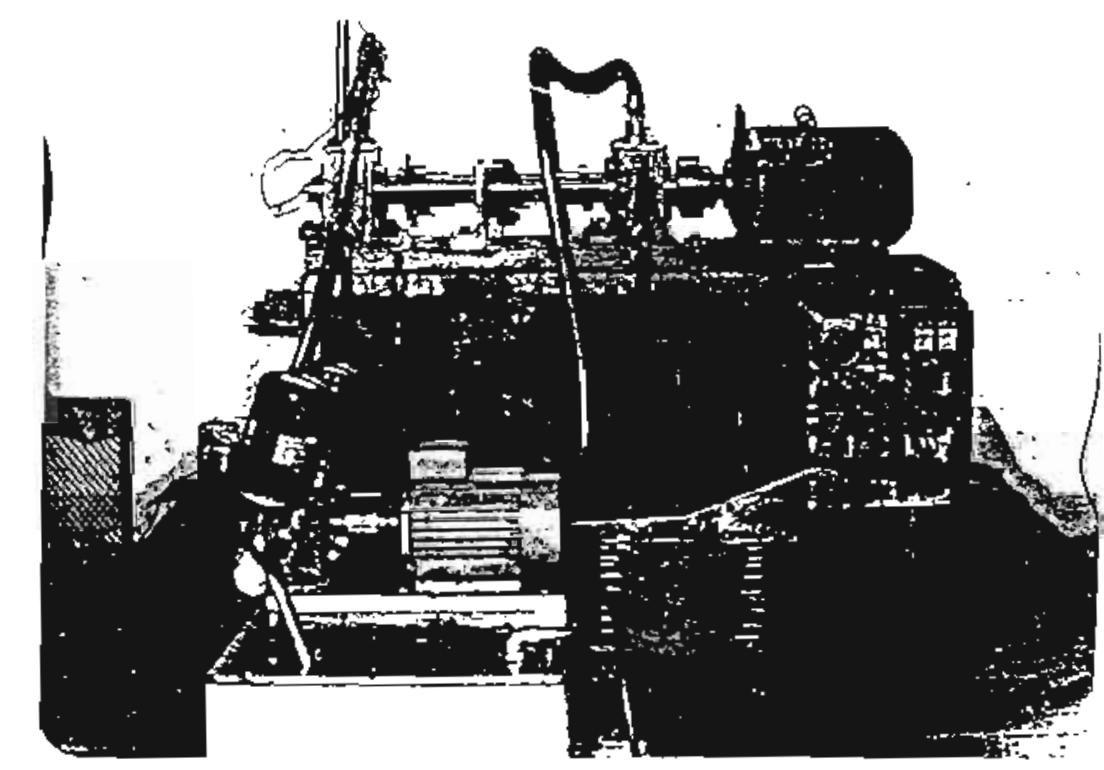

FiglalGeneral view of the test rig 


\section{THE TEST RIG}

The test rig is of the power circulatng tyoe composed, as shown in Fig.(2), of wo shalts carrying the two test gears at one side and a pair of slave gears at the other side The driven shatt is composed of two parts connected together by a tlange coupling. The test rig is loaded. as shown in the ligure, by applying dead weights at the end of a lever fastened to the slolled flange while the other flange is tked. thus twisting each part of the shalt relative to the olher. The drlving shat carries a graduated torque coupling to indicate the load on the machine. The lest rig is driven by $6 / 7.4 \mathrm{~kW}$ a.c. motor when running at speeds 1500 and $3000 \mathrm{rpm}$, respectively. The test rig is forced lubrication by a gear pump driven by $2 \mathrm{HP}$. 1460 revimin motor. Fig.(3) shows a general view of the test rig.

\section{HEAT TREATMENT TECHNIQUE}

The heat treatment techntque used in this sludy was carburizing lollowed by hardening and then tempering. The test gears and other test specimens for case depth, distrbution of carbon in the case depth and microstructure examinations were completely surrounded with a mixture composed from $80 \%$ charcoal and $20 \% \mathrm{BaCo}_{3}$ and packed in the three carburizing boxes according to the required case depths. The boxes were covered and all openings were luted with a non-cracking loam to prevent air from penetrating into the boxes. The first box conlatning group $A$ of test gears was placed in an electic furnace and heated gradually at the rate of $50^{\circ} \mathrm{C}$ per hour up to the carburizing temperature of $920^{\circ} \mathrm{C}$ and kept for a predetermined period of time $=7.5$ hrs according to Fig.(4) and table (4-a). The box was cooled in fumace. The second and thlid boxes were placed in the same furnace and heated according to Fig. (4) and table (4-a). After reaching the room temperature, the test gear were preheated in salt bath furnace to $865^{\circ} \mathrm{C}$ lor one hour to be hradened by oil quenching. Alter quenching the test gears were tempered by heating them in electric furnace according to the requlred case hardness as shown in Fig.(4) and table (4-b). Specifications of carburizing. hardenlng and tempering furnaces and quenching oil are given in appendix (1 and 2).

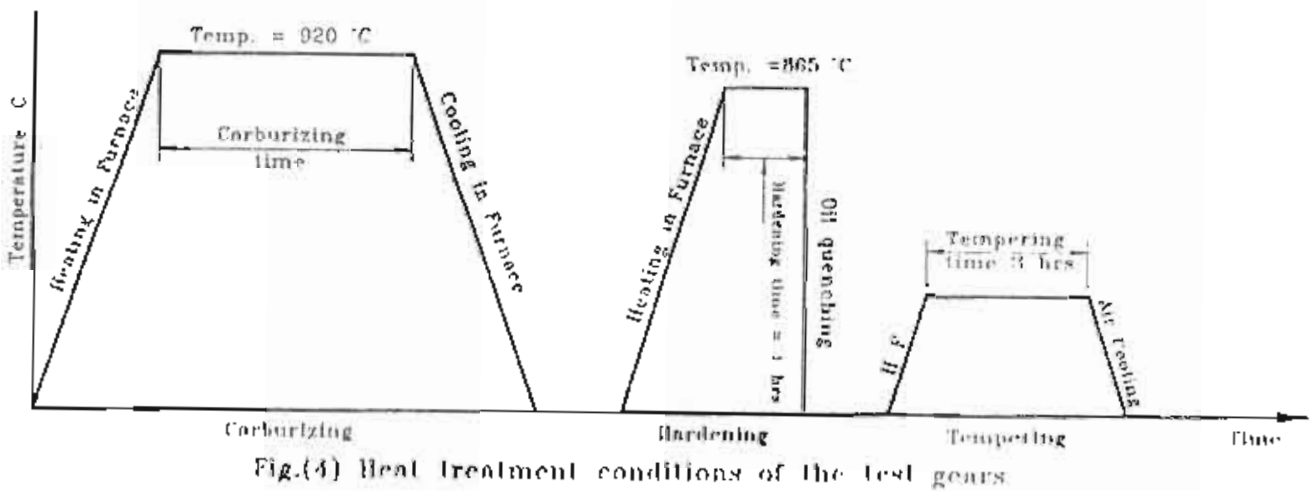

\begin{tabular}{|l|c|c|c|}
\hline Carburizing procoss & Group $A$ & Groun $\mathrm{e}$ & Group $\mathrm{C}$ \\
\hline Carburlizing time, hrs & 7.5 & 18 & 28 \\
\hline Case depth, inm & 0.5 & 1.2 & 2 \\
\hline
\end{tabular}

\begin{tabular}{|l|c|c|c|}
\hline Tempering process & Group o & Group E & Group $F$ \\
\hline Tempering temperature, ${ }^{\circ} \mathrm{C}$ & 170 & 180 & 190 \\
\hline Case hardness, HRC & 58 & 52 & 46 \\
\hline
\end{tabular}

Tabia (4-b) Case hardness and required remperature 


\section{EXPERIMENTAL PROCEDURE}

Tests were carrled out for test gears at normal looth loads of $5,7.5$ and $10 \mathrm{KN}$ runing at constant speed equal to $1460 \mathrm{rev} / \mathrm{min}$ which correspond to langentlat transmilted loads. torques and Iransmiltiod nowers glven In Appendix (3). To sludy the olfecl of the case deplh and case hardness on the wear rate and surface capacliy of the gears of circular-arc looth-prolile. tests were carrled out for a groups of rest gears with case depths $0.5,1.2$ and $2 \mathrm{~mm}$ and case hardness of 46.52 and 58 HRC. Also, the same tesis were carried out on the lesi gears without any heat treatment to show the difference between them and the case hardeneo gears. Thirty palrs of test gears were used lor these experiments. Tests were carried out using rorce lubricating system at rate of 2 L/min, specifications of the iubricating oil are given in appendix (2). Temperature of the lubricating oil in the tes! gear box was measured using a sensor and a temperature indicator mounted on the lest gear box.

The metal removed after each run was measured by welghing the lest gears before and ailer each test by a digital and analogue balance of accuracy $1 \times 10^{-5}$ gram and capacily $2000 \mathrm{gram}$. type Chyo Jupiter C2-2000. serial No. 30559. made in Japan The test gears were washed before woighing using an ultrasonle cleaning tank lype No. 323/201, serial No. 337226. $40 \mathrm{KHZ}$ irequency, 150 watts output and $220 \times 130 \times 150 \mathrm{~mm}$ internal dimensions made in Germany and then dried by a stream of compressed air.

Wear rate is calculated from the relationship

$$
\text { Wear rate }(W A)=\frac{\text { Accumulated weight of removed metal }}{\text { tooth load } x \text { number of revolutions }}
$$

\section{EXPERIMENTAI, RESULTS}

1 - Weight of removed metal during running:

Fig.(5) shows the change in accumulated weight of removed metal (AWRM) for pinion and wheal whth number of revolutions at different tooth loads (pinion and wheel withoul heat treatment). Fig. (6, 7 and 8) show the change in AWRM for pinion and wheel with number of revolutions at different looth loads and case hardness for case depths equal 10 $05,1.2$ and $2 \mathrm{~mm}$, respectively. it is clear from these figures that the AWRM is rapoidly increases with increasing the number of revolutions for the plnion and wheel without heat ireatment than that of the casa hardened gears at any case deplh or case haroness. AWRM increases with increasing tooth load for all cases of case hardened or unhardened gears. AWRM for unhardened wheol is greater than that of the unhardened pinion. AWRM for hardened gears of case depth equal $2 \mathrm{~mm}$ is greater than that of the hardened gears ol case depth equal 0.5 $\mathrm{mm}$. and AWAM for hardened gears of case depth equal $1.2 \mathrm{~mm}$ give a minimum values lhan that of case depth equal $2 \mathrm{~mm}$ or $0.5 \mathrm{~mm}$. this is for the same tooth loads and case hardness. That is to say an optimum value of the case depth is lound. Also for all cases of tests. AWRM for the smallest and the highest case hardness ( 46 and $58 \mathrm{HRC}$ ) of the case hardened gears are greater than that of the hardened gears of case hardness equal 52 HRC. and AWRM or hardened gears of case hardness equal 46 HRC is greater than that of the hardened gears of case hardness equal 58 HRC. That is to say an optimum value of the case hardness is found.

Fig.(9) shows the looth breakage due to surtace lailure for wheel teeh and surface lailure of the pinton teeth at tooth lead equal $10 \mathrm{KN}$ and $4.03 \times 10^{6}$ revolutions. Fig.(10) shows the toolh breakage due to suriace failure for the wheel teeth and the surface failure of the pinion teeth at $7.5 \mathrm{KN}$ and $1.05 \times 10^{7}$ revolution. Fig.(11) shows the surface failure of the gear teeth al toolh load equal $5 \mathrm{KN}$ and $1.58 \times 10^{7}$ revolutions.

For all case hardened test gears there is no tooth breakage at all tests, lor example. Fig.(12) shows a plcture of surface for pair of gear teeth after $6.7 \times 10^{7}$ revolutions, and $7.5 \mathrm{kN}$ tooth logd,

A curve fitting for these results has been found using Grapher soltware which glves the lollowing equation

$$
\text { AWRM } \left.=\left(8.75 \times 10^{-9}-0.2126\right) \mathrm{N}^{(0.4016} \cdot 1.5252\right)
$$

Ranges of constants given in this equation depend on the tooth load, case depth and case hardness. The fitting equation for each curve is Indicated in Fig.(6, 7 and 8$)$ 


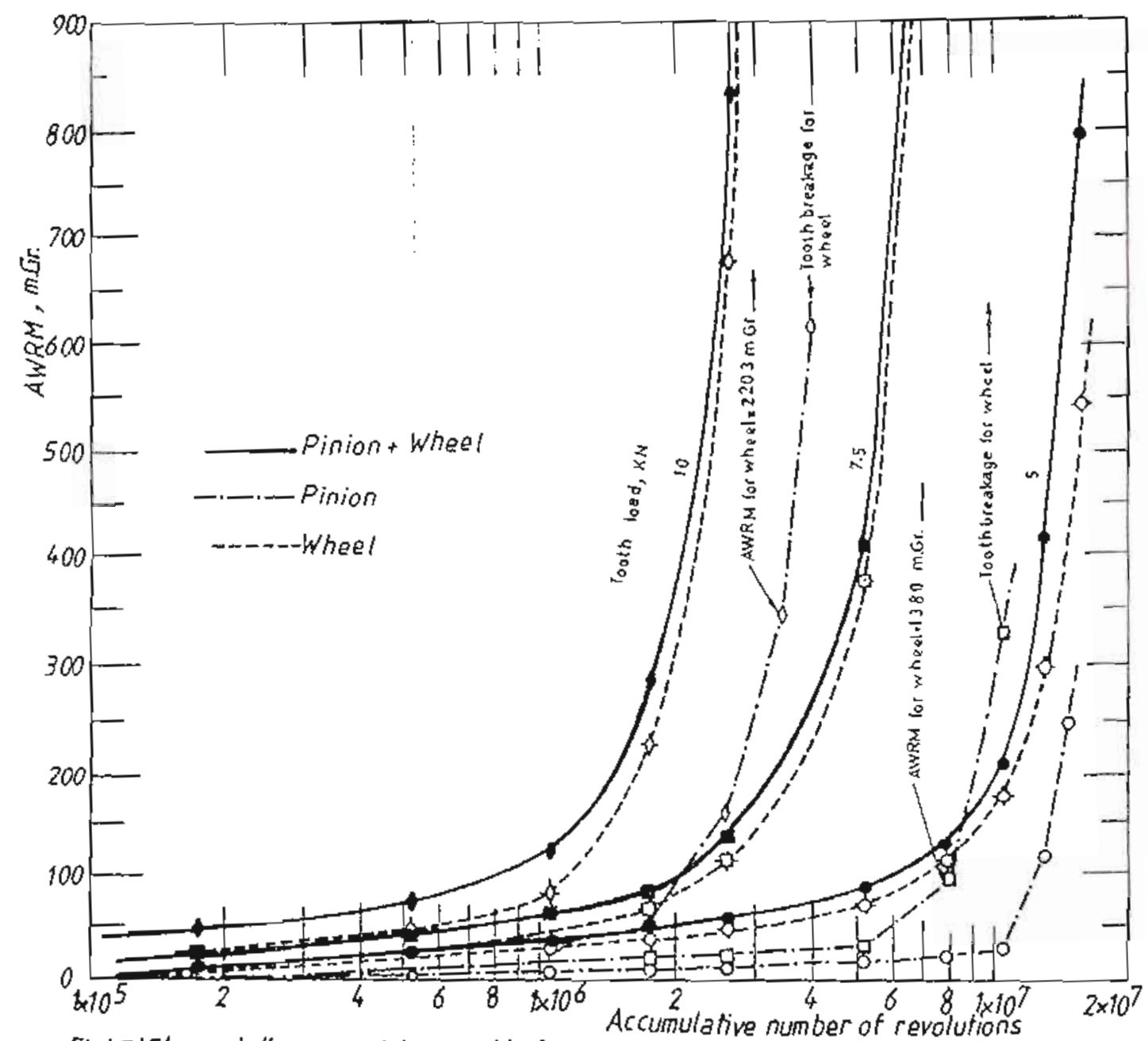

$\mathrm{Fig} / 5 /$ Change in the accumulated weight of removed metal( AWRM) for un hardened pinion and wheel whith change of accumulated number of revolutions at different footh loads 


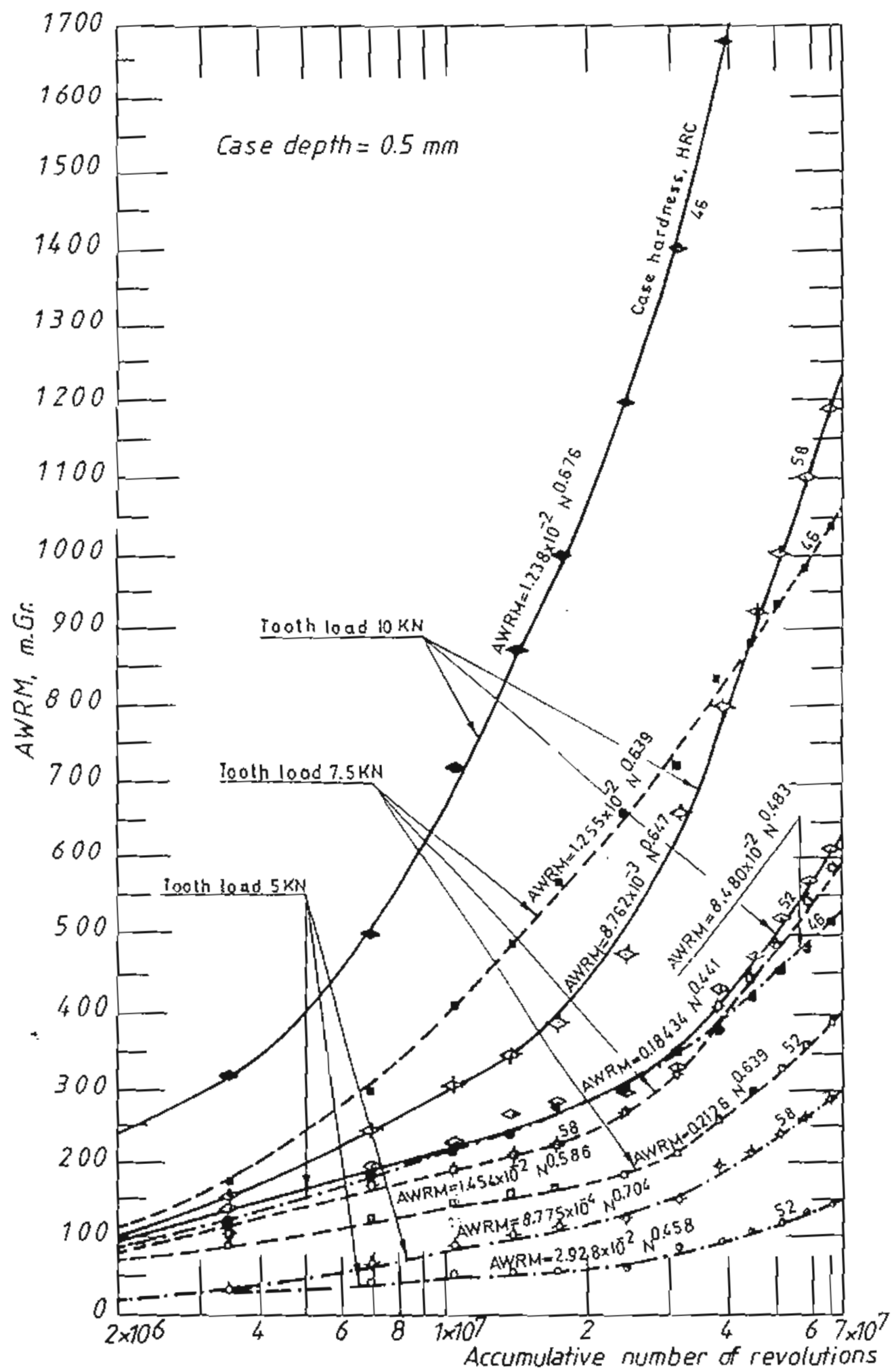

Fig. (6) Change in accumulated weight of removed metal for pinion and wheel with the change of accumulated number of revalutions at different tooth load and different case hardness at constant case depth $=0.5 \mathrm{~mm}$ 


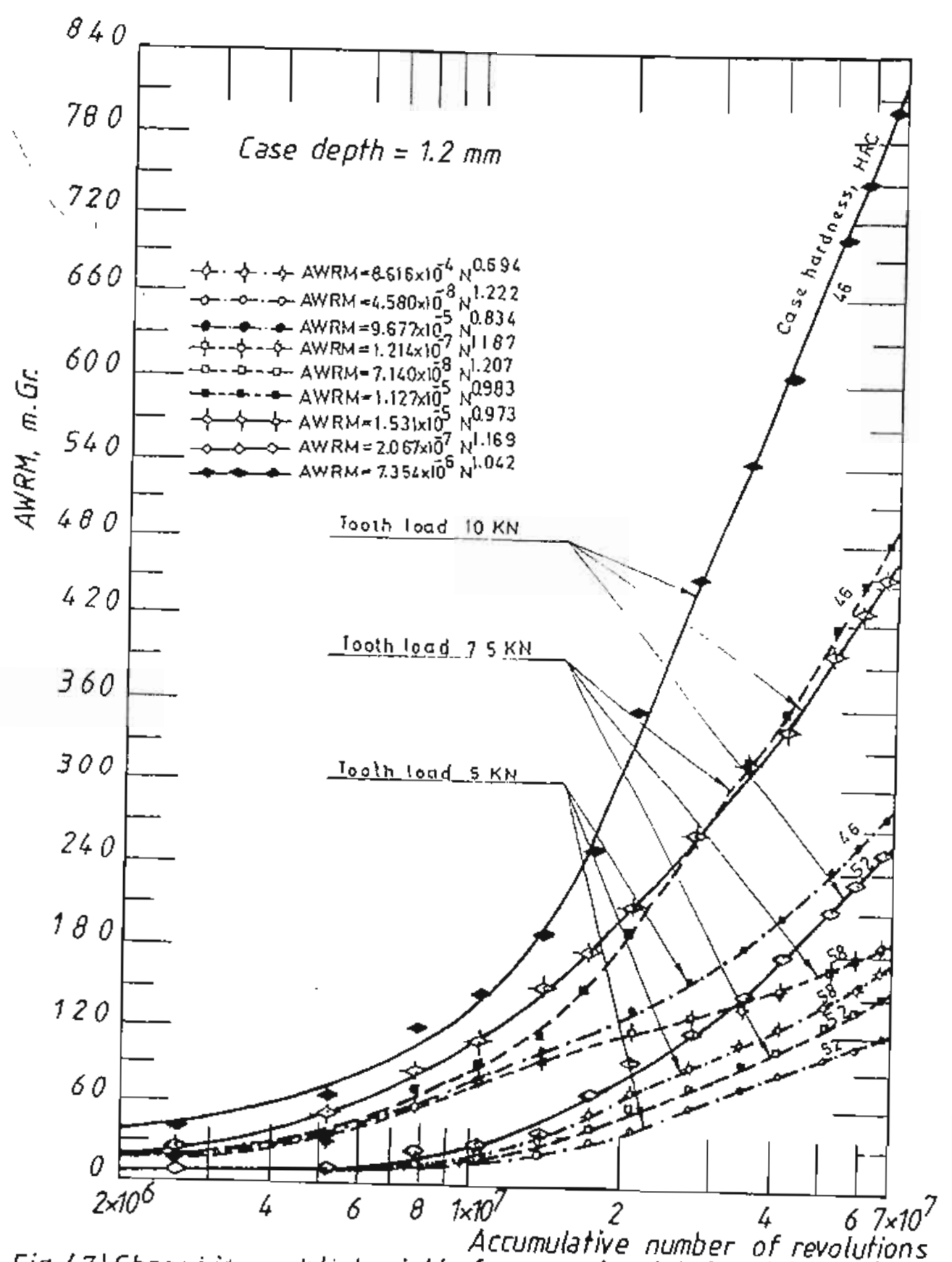

Fig (7) Change in acculated weight of removed metal for pinion and wheel with the change of accumulated number of revolutions at different tooth load and different case hardness at constant case depth $=12 \mathrm{~mm}$ 


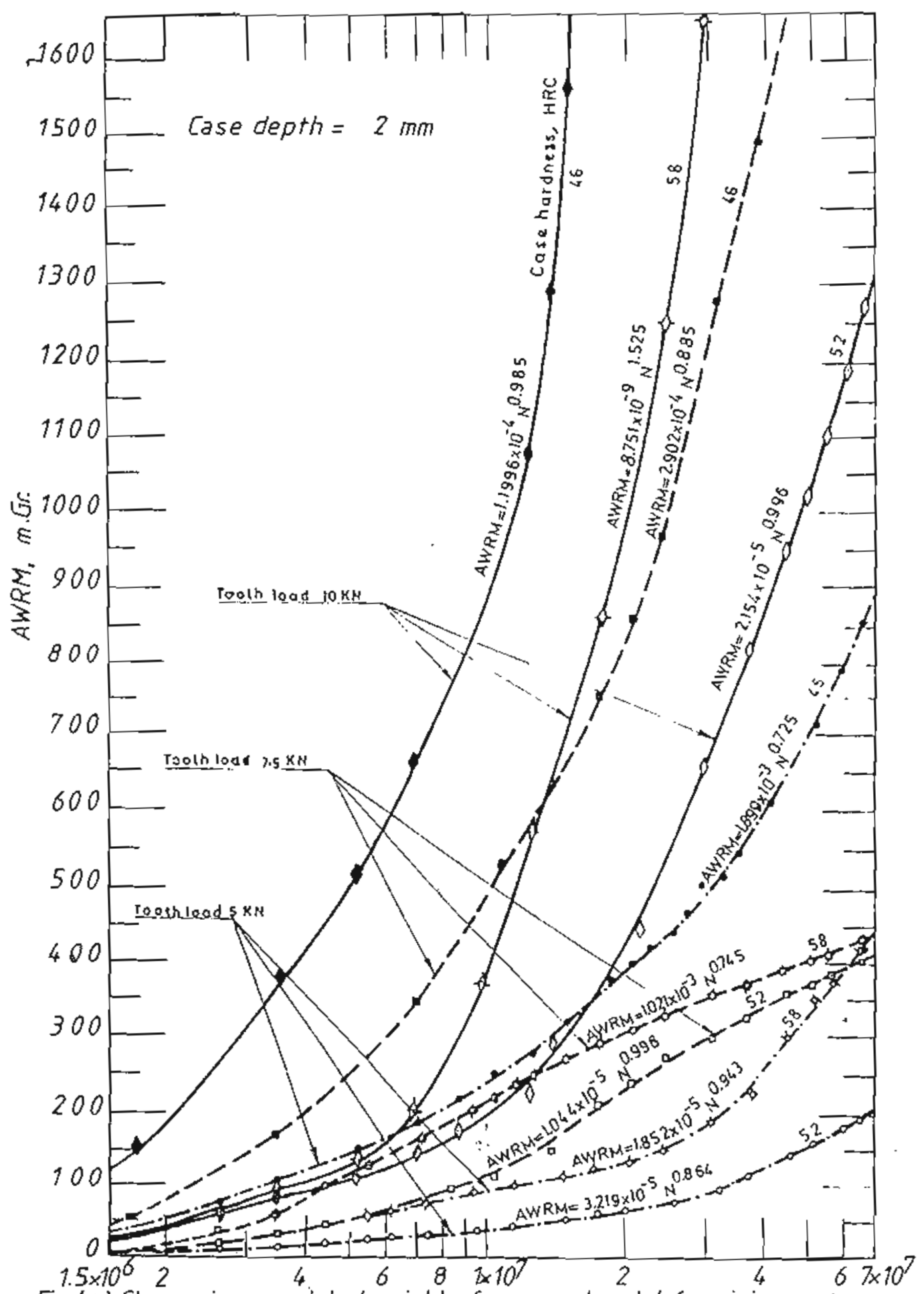

Fig (g) Change in accumulated weight of removed metal for pinion and wheel with the change of accumulated number of revolutions at different tooth load and different case hardness at constant casedepth= $2 \mathrm{~mm}$ 

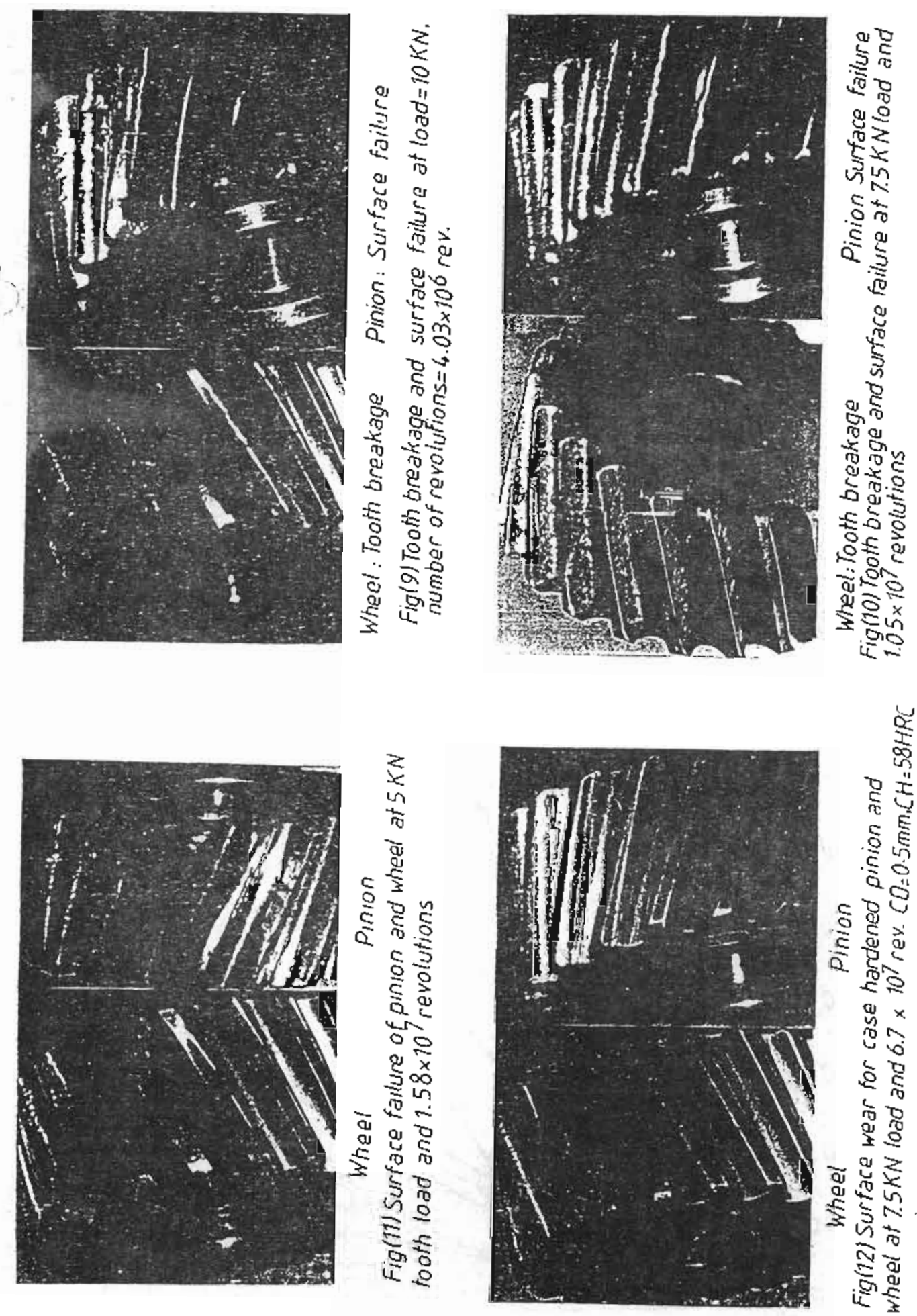


\section{2- Eftect of Tooth Load on the Wear Rate}

Fig.(13) shows the change of the weat rate of tho hardened lest gears with the change of tooth lozd at different case depths and case hardness. From this figure it is very clearly noliced that the wear fate Increases with increasing the tooth load for lested gears. Wear fale lor case depth of $2 \mathrm{~mm}$ is grealer than that for the case depth equal to $0.5 \mathrm{~mm}$, wear rate for lest gears of case deph equal to $1.2 \mathrm{~mm}$ gives minimum values for all the rested gears This means that an optimum case depth is found. Also for all case depths. wear rate of the test gears with hardness (46 HRC) is greater than that for the gears of (58 HRC). wear rate is minimum for lest gear with medlum hardness ( 52 HRC). This means that there is an optimum value of the case hardposs.

A curve fitting for these results is derived using Grapher sotware which gives the equation

$$
\text { Wear rale } \left.W R=\left(3.593 \times 10^{-17} \cdot 1.009 \times 10^{-11}\right) P^{(0.4178} \cdot 2019\right)
$$

Aanges of the constants given in this equation depend on the case depth, and case hardness. The fitting equation for each curve is indicated in Fig.(13).

\section{3- Effect of Case Depth}

Fig.(14) shows the change of the wear rate of the hardened test gears with the change of the case depth for difterent case hardness at different tooth loads. From this ligure it is noticed that, wear rate decreases with increasing the case depth to a certain value of the case and then increases with increasing the case depth for all test conditions.

A curve fitting for these results has been found using Grapher software which gives the tollowing equetion

$$
W A=A+B . C D+C . C D^{2}
$$

Where $A, B$ and $C$ are constants. which depending on the applied tooth load and case hardness of the test gears. The fining equation for each curve is indicated in Fig (15)

From the above equations and Fig.(14) an optimum value of the case depth is calculated and equal to $1.004-1.239 \mathrm{~mm}$ for all tes! conditions with mean value of $1.094 \mathrm{~mm}$.

4- Elfect of Case Hardness

Fig.(15) shows the change of the wear rate with the change of case hardness at different case depths and different tooth loads. From this figure, it is noticed that wear rate decreases with Increasing the case hardness for all case deoths at different tooth loads to a certain value and then increases with increasing the case hardness of the test gears. A curve fitting for these resuts has been found using Grapher software which gives the following equation

$$
W R=D+E \cdot C H+F \cdot C H^{2}
$$

Where $\mathrm{D}, \mathrm{E}$ and $\mathrm{G}$ are constants, which depending on the case depth and applied rooth load on the test gears. The fitting equation for each curve is indicaled in Fig (15).

From the above equation and Fig.(15) an oplimum walue of the case hardness of the hardened test gears is found to be $53.23=53.98$ HRC, for all applied tooth loads and case deptins, with mean value of $53.5 \mathrm{HRC}$.

\section{DISCUSSION OF TIE EXPERIMENTAL RESULTS}

During geas ruming, the surface and subsurface of the teeth in mesh are subjected to cension. comprassion and shear stresses. This surface contact is made between crests of surface waves. A number of actlons take place. hesuy rubblng and deformatlon of malal. olowing by "hills" on the harder material through the solter material, which results in breaking off worn particles'and creatlng surfaces of difterent roughness and finally welding of minute high areas that have been rubbed clean. The minute weids break immediately. as motion continues. but may break at another section so that metal is transferred from one surface to the other. New surface roughness is formed, some to be plowed ofi to form wear panicles.

With Increasing the number of revolutions, a very larige number of minute cracks form in and below the surface which may grow and join togther. Eventually. small bits of melat are separated and forced out, leaving pits. surface fatlgue may occur. By further increasing the number of revolutions. pits continue to form and enlarge as edges crumble or pils collides into each olher. Eventually the designed looth shape is delormed generating noise and vibration 


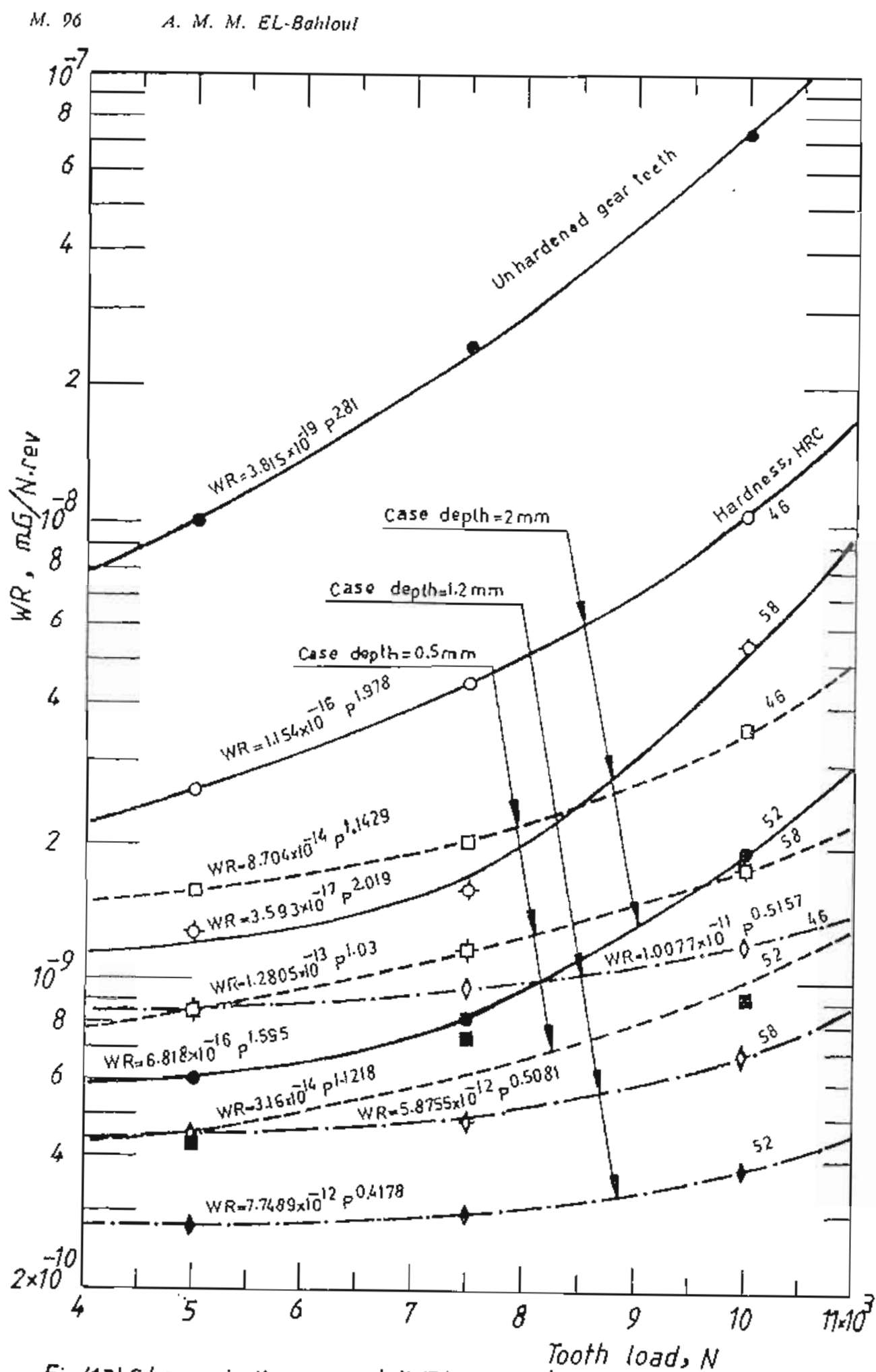

Fig (13) C hange in the wear rate(W/R) of case hardened gears with the change of the applied tooth load atdifferent case depths for different case hardiness 


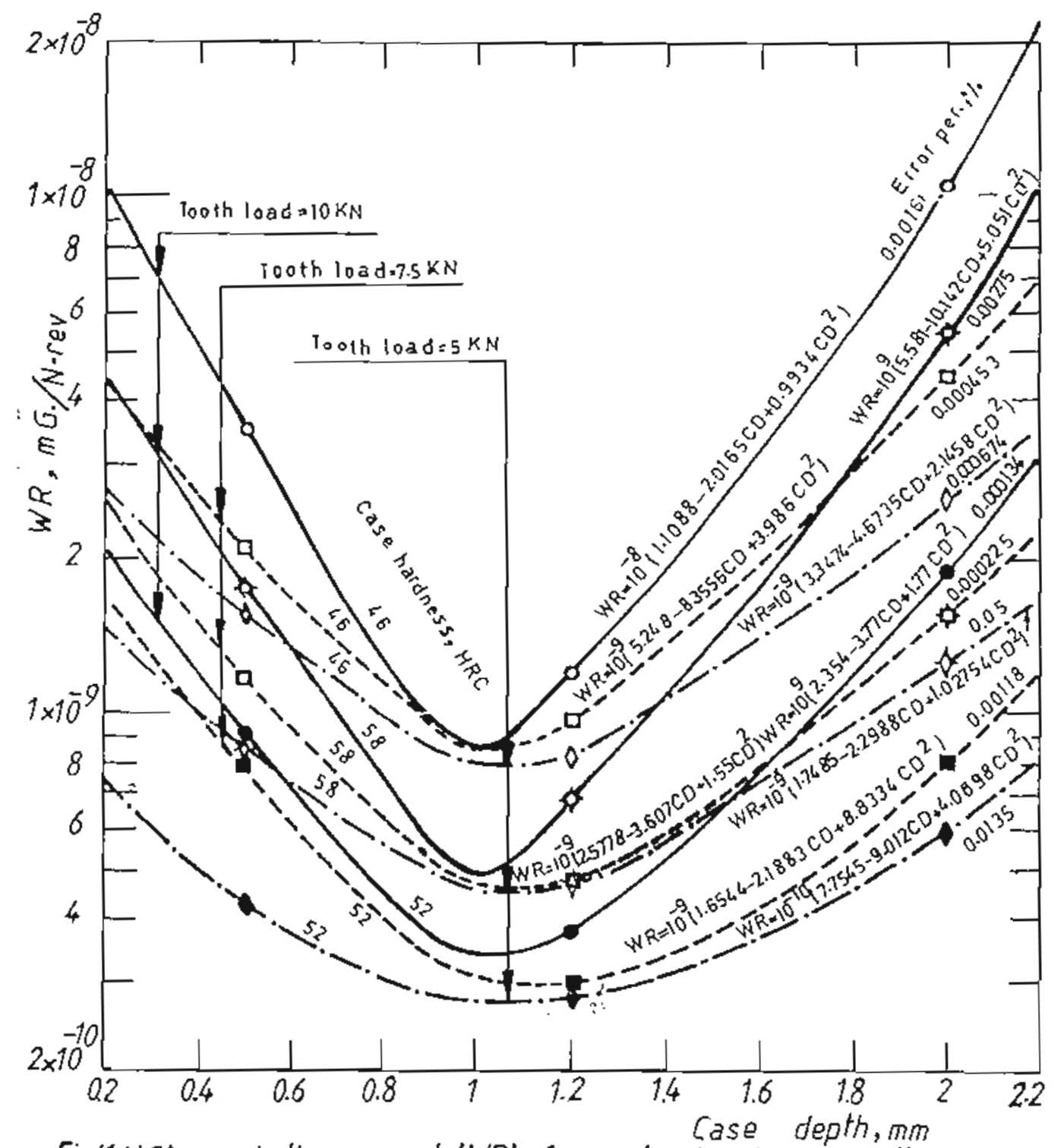

Fig(14)Change in the wear ratel WRl of case hardened gears with the change of case depth at different looth loads for different case hardness 


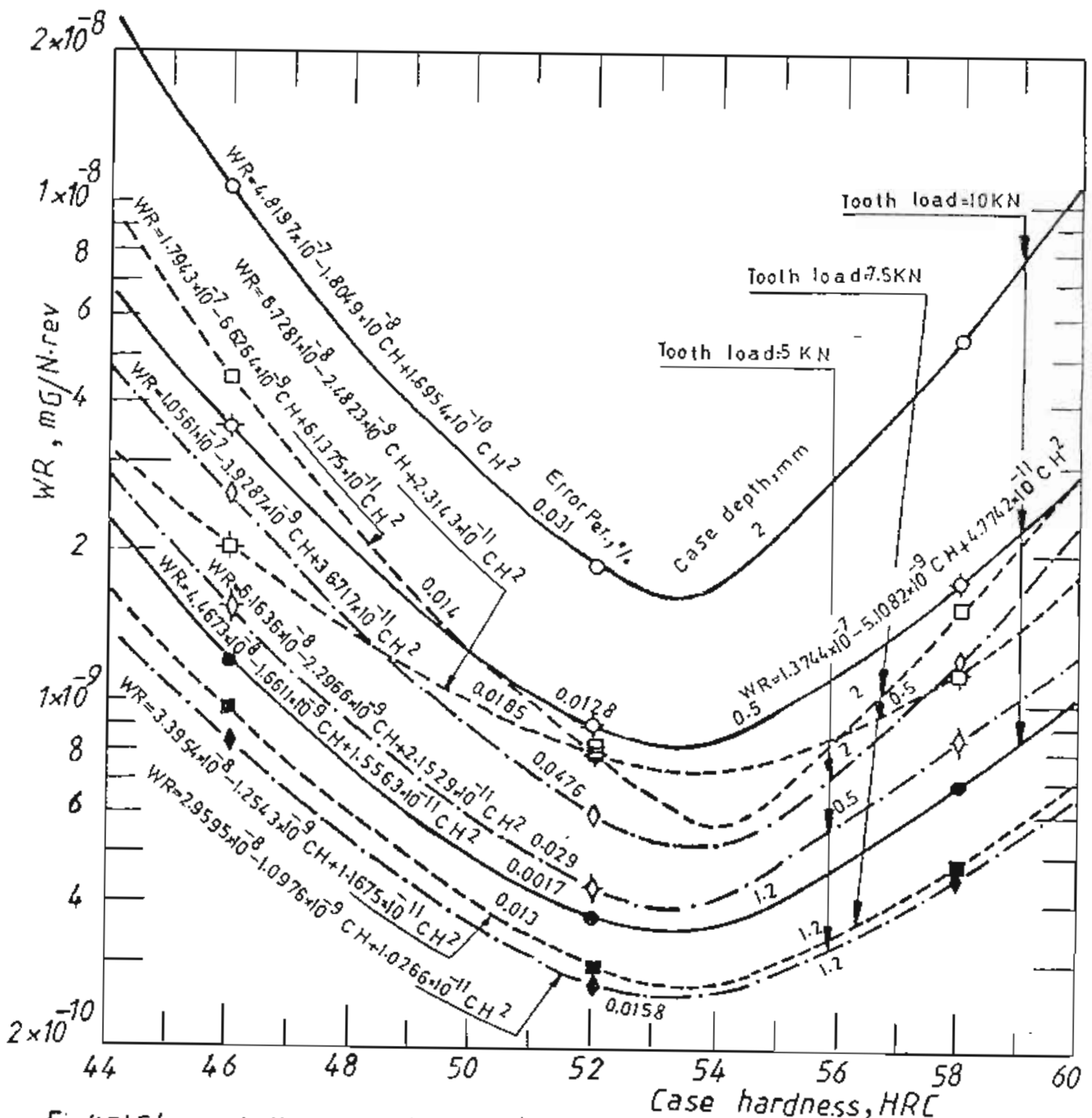

Fighs/Change in the wear rate(WR/ of case hardened gears with the change of case hardness at different tooth loads for different case depths. 
With Increase of amount of removed metal the tooth thickness decreases which may lead to strength sailure and tooth breakage.

With lncrease of appled tooth load the area of contact and the tooth deflections along and across the path of contact increese. This leads to unstable lubrication conditions and difficulty of oil ilim formation. Heat generation and contact temperature for the area of contact increase. strengit of the material decreases. accordingly removed metal and wear rate increase

For increasing the case depth and/or case hardness yeild limil and uitimate strength of the case incraase, wear resistance increases consequently wear rate decreases to a cerlain value. By increasing the case depth and/or case hardness, the contact area of the teeth did not easly develcp plastlc deformation, therefore it induced a relatively small contact area and high contact pressure. In the hardened layer composed of fine structures, such as martensite and retained austenite, the thermal conductivity is relatively low and the flash temperature becomes hlgh. Therefore the amount of waight of removed metal and wear rate increases.

The Increase of relained austenite resulting from further increasing the case depth, decrease the yleld and ultimate stress of the material. It also decreases the fatigue limit and increase the crack propagation. This is believed 10 be the reason of increase of the wear rate. Also for largest case depth and case hardness, pigidity of the case hardened gear teeth increases, followed by increase of vibratlon level and dynamic load. tooth further increase of weight of removed metal and wear rata.

\section{CONCLUSION}

Wear rate for case hardened gears decreases with increase of case depth tending to reach a minimum at $1.1 \mathrm{~mm}$ case depth and increases again with further increase of the case depth.

Wear mate for case hardened gears decreases with increase of case hardness tending to reach a minimum at 53.5 HRC and incresses agaln with increase of case hardress.

Wear rate of hardened gears of circular-arc tooth-profile increases gradually wilh increase of applled tooth load. For unhardened gears this rate is about 4 to 192 times the wear rate for case hardened gears. This range depending on the tooth load, case depth and case hardness.

Empirical tormulae are derived to help tho designer to estimate the wear rate and accumulaled weight of removed metal from the design parameters:

- Wear rate with tooth load

$$
W A=\left(3.593 \times 10^{-17}-1.008 \times 10^{-11}\right) P^{10.4178 \cdot 2.019)}
$$

- Wear rate with case deptin $W R=A+B . C D+C . C D^{2}$

- Wear rate with case haroness

$$
W A=D+E \cdot C H+F \cdot \mathrm{CH}^{2}
$$

- Accumulated weight of removed metal with number of revolution AWRM $\left.=\left(8.75 \times 10^{-9}-0.2126\right) \mathrm{N}^{10.4018} \cdot 1.5252\right)$

Values and ranges of the constants given in the above equations depending on the experimental test conditions.

For unhardered lest gears. tooth breakage occured at looth load of $10 \mathrm{KN}$ and $4.03 \times 10^{6}$ revolutlons, also at tooth load of $7.5 \mathrm{KN}$ and $1.05 \times 10^{7}$ revolutions. There is no tooth breakage at tooth load of $5 \mathrm{KN}$ and $1.58 \times 10^{7}$ revolutions. For case hardened gears, there is no tooth breakage during running to $6.7 \times 10^{7}$ revolutions for all test conditions.

\section{REFERENCES}

1- Altla, A. Y. and Fahmy, M. A. K., "Mear of gears of double circular-arc tooth.profile". ASME paper No. 77-DET-59, June, 1978, (American Society of Mechanical Engineers. Now York. NY 10017. U.S.A.).

2- El-Bahloul, A. M. M. "Wear of gears of circular-arcntooth-profile: Effect of tooth load and speed of rotation", on Proc. 3rd Int. Conf. on Production Engineering Design and Control, Alexandrla University, Egypt, 12 - 14 December, 1986.

I-Bahloul, A. M. M., "Wear of gear of circular-arc tooth-protile: Effecl of helix angle and oil viscosity". Tribology International Vol. 20 No. 4. August 1987, $205 \cdot 209$. 
4- El-Bahloul. A M. M.. "Wear of Involute helical and circular-arc gears (A comparatlve study)". Wear, 122 (1988), $103-114$.

5- El-Bahloul. A. M. M.. "Load-carrying capacity for gears of circular-arc tooth-prolile", Wear. 129. $1989.183-193$

6. Coy, J. J.. Townsend. D P., and Zaretsky. E, V., "Dynamic capacily and surlace tatigue life for spur and helical gears". ASME, Journal of Lubrication Technology. Series F, Vol, 98, 1976. $P P 267-276$.

7. Fullta, K.. Yoshida, A., Yamamolo, T., and Yamada, T., "The suriace durabillty of the case-hardened nickel chromium steel and its optimum case depth", Bulletin of the JSME, Vol. 20. No. 140, 1977, PP 232 - 239.

8- Gang. D., Chui. X, and Yang. $Y$. . "A method to determine the optimum eflective case depth of gears", 4th European tribology congress, Ecully - France, 9-12. September 1985 PP 1 - 5

9. Davles, W. J., "Novlkov gearlng", Machinery, London, 96. January 13. 1960, PP 64 - 73.

10. Wells, C. F. and Shotter, B. A., "The development of CirCarC gearing", AEI Eng., March April 1952 PP 83 - B8.

11 - Chironis. N., "Design of Novikov gears", Prod. Eng. (N.Y.), September 17, 1962. PP 91 - 102.

12- French, M. J.. "Conformlly of cliculer-arc gears". J. Mech. Eng. Sel. Vol. 7. No. 2. 1986, PP $220-223$

13- Dyson. A., Evans, H. P. and Snidle. R. W. "Widhaber-Novikov circular arc gears: geometry and kinematics". Proc. R. Soc., London, Ser. A. 403. 1986. PP $313-340$.

\section{APPENDIXES}

\section{Appendix (1)}

\begin{tabular}{|c|c|c|c|}
\hline Specificalion & $\begin{array}{l}\text { Carburizing Funace } \\
\text { Electric Furnace }\end{array}$ & $\begin{array}{l}\text { Hardening Furnace } \\
\text { Sait baih } \mathrm{F} \text {. }\end{array}$ & $\begin{array}{l}\text { Tepering } F \text {. } \\
\text { Eloctric } F\end{array}$ \\
\hline $\begin{array}{l}\text { Dimension } \\
\text { Type } \\
\text { Volt } \\
\text { Power } \\
\text { Temperature } \\
\text { Made in }\end{array}$ & $\begin{array}{c}600 \times 1200 \times 600 \\
H N 27 / 12 \\
3 \times 380 \\
40 \mathrm{KVA} \\
960{ }^{\circ} \mathrm{C} \\
\text { Czechosiovakla }\end{array}$ & $\begin{array}{c}\text { D } 1000 \times 1000 \\
\text { DAW } \\
3 \times 380 \\
85 \mathrm{KVA} \\
860 \text { - B80 }{ }^{\circ} \mathrm{C} \\
\text { Germany } \\
\text { Fulmina }\end{array}$ & $\begin{array}{c}\text { \% } 800 \times 1000 \\
\text { KPA } 20 / 6 \\
3 \times 380 \\
22 \mathrm{KVA} \\
650{ }^{\circ} \mathrm{C} \\
\text { Czechoslovakia }\end{array}$ \\
\hline
\end{tabular}

Tabio (i) Specilications of calburizing. hardening and lempering Furnacas.

Appendix (2)

\begin{tabular}{|l|c|c|}
\hline \multicolumn{1}{|c|}{ Characteristics } & Lubricallng orl & Quonching oil \\
\hline Kinematic viscosity cSt at $40^{\circ} \mathrm{C}$ & 599 & 30.9 \\
Kinematic viscosity cSt at $100^{\circ} \mathrm{C}$ & 32.7 & 4.7 \\
Speclfic gravity & 0.921 & 0.869 \\
Pour point, max. ${ }^{\circ} \mathrm{C}$ & -9 & -18 \\
Flash polnt, min ${ }^{\circ} \mathrm{C}$ & 174 & 216 \\
Viscosily index & 89 & 103 \\
Flmken Ok load 40 lb (18Kp) & 60 & - \\
\hline
\end{tabular}

Table (2) Characterislics of the Iubricating and quenching oils.

Appendix (3)

\begin{tabular}{|c|c|c|c|}
\hline $\begin{array}{c}\text { Normal tooth load } \\
\text { KN }\end{array}$ & $\begin{array}{c}\text { Transmitted load, } \\
\text { KN }\end{array}$ & $\begin{array}{c}\text { Transmilted torque } \\
\text { KN.M }\end{array}$ & $\begin{array}{c}\text { Transmilled powat } \\
\text { KW }\end{array}$ \\
\hline 5 & 4.19 & 0.192 & 29.5 \\
7.5 & 6.29 & 0.288 & 44.3 \\
10 & 8.39 & 0.384 & 59.1 \\
\hline
\end{tabular}

Table (3) Normal tooth load, transmitted load, 10rque and transmitted power. 